\title{
An Investigation Study of TV Watching for Albanian Children and Teenagers Living in Tirana
}

\author{
Blerina Aliaj \\ Ext. Lecturer, Faculty of Education \\ Aleksandër Moisiu University \\ Corresponding Author \\ Fatjon Nurja \\ The University of Shkodra "Luigj Gurakuqi" Albania \\ Ermal Tahiri \\ High School of Football "Loro Borici" \\ Florian Muca \\ Albanian Sports Science Association
}

Doi: 10.2478/jesr-2019-0047

\begin{abstract}
The time children and teens spend in front of TV is one of the most disturbing phenomenon of parents not only in Albania but around the world. Watching TV for a considerable amount of hours is associated with a variety of problems in children, such as obesity, behavioral problems, sleep problems, insufficient engagement in the accomplishment of academic tasks and many other problems. The purpose of this study is to provide a broader overview of the amount of time Albanian children and teenagers in 1st, 5th, 9th and 12th grades spend watching TV. Do they watch more TV before they go to school or when they return from school? Is there a difference between boys and girls in the time they spend in front of the TV? But is there a difference between different age groups in this regard? The study was conducted in Tirana where $(n=698)$ children and teenagers participated in this study. It turned out that the children and teenagers interviewed watched more TV as they returned from school compared to before going to school. No statistically significant differences were observed between the boys and girls interviewed. No statistically significant differences were observed even between the classes taken in the study, but teenagers were found to watch slightly more TV than children. Important study resolutions are that before going to school most of them do not watch TV at all and after returning from school the highest percentage of the participants watch 1 to 2 hours of TV per day, which is acceptable for their age.
\end{abstract}

Keywords: TV watching, children, Tirana, sleeping

\section{Introduction}

TV watching is one of the most concerning phenomenon for parents who have children and teenagers. According to (Bar-on, 2000), children and teenagers in America spend more time watching TV than at school. They spend 15000 hours on average watching TV and 12000 hours in class during their graduation years. On average a child and / or teenager in America spends 3 
hours a day watching TV, and over the past 10 years these figures have had no significant decrease. Children and teenagers watching TV is associated with a number of positive and negative effects.

Access to TV watching is associated with a number of health and behavioral problems. Overweight and obesity can be mentioned in health problems that lead to a number of other diseases, such as diabetes, cardiovascular disease or sleep problems (Gortmakers, 2006).

In Albania studies show that the prevalence of overweight is $10.9 \%$ and obesity $5.7 \%$ among children (Jarani et al., 2016). And the prevalence of overweight and obesity is $21 \%$ (Jarani et al., 2018) among Albanian children in Balkan. Short studies with students show that there is a negative relationship between the time of watching TV and their academic outcomes (Strasburger, 1986). Aggressive behavior is one of the other problems that long-term exposure to inappropriate television programming causes to children (Liebert, 1986). Also exposure to uncontrolled and long hours of TV is associated with risky behaviors including alcohol and drug use, and accelerated onset of sexual activity (Villanim, 2001).

However, if children are exposed to moderate-time TV watching, this can positively influence a more diverse viewpoint than the parent or teacher viewpoint, induce prosocial behavior, and positively affect the child's attention and memory ( AACHAP, 2014; Karaj, 2000) Various studies suggest that the relationship between TV and child development is complex. It depends on the characteristics of the child, the family and the social context. It also depends on the type of programming that children watch. Different programming can be educational and positively affect the cognitive development of the child (Kostyrka, Cooper, \& Simpson, 2017).

But in Albanian reality, how many hours do children spend in front of the television? Do they watch more TV before or after school? Does their gender affect the hours they watch TV?

The purpose of this study is to provide a more detailed overview of the time children and adolescents in 1st, 5th, 9th and 12th grades spend in front of the television. Whether, they watch more TV before going to school or after returning from school. The purpose of this study is also to look at the difference between children of different grades as well as the differences between boys and girls in the time they spend in front of the TV.

\section{Methodology}

\subsection{Sample}

In this study ( $n=698$ ) children and teenagers participated. Questions about how many hours children and teenagers watch tv $(n=669)$ were answered and 29 questionnaires were invalid. Questions about how many hours children and teenagers watch television after school were answered $(n=683)$ and 15 questionnaires were invalidated. The first group included $(n=324)$ boys and $(n=345)$ girls. The second group included $(n=328)$ boys and $(n=355)$ girls.

Children and teenagers were also divided on the basis of their classes. In the first grade $(n=$ $127)$ students participated, in the fifth grade $(n=167)$ students, in the ninth grade $(n=194)$ students and in the 12th grade participated $(n=210)$ students.

\subsection{Procedures}

This study was conducted in Tirana. The study were performed in 8 schools selected among a pool of 56 schools. Also the classes were selected randomly from the pool of classes/ school.

\subsection{Analysis}

The study was conducted in Tirana. The target group of the study group was explained the purpose of the study, then they completed the questionnaire. After the completed questionnaires were obtained, all data were entered and processed with tables in Excel. Descriptive statistics for frequency, comparison and mean values were performed in SPSS software packages 20 version. 


\section{Results}

Referring to Table 1, it can be observed that $55.3 \%$ of the children and teenagers interviewed do not watch TV before going to school. $19.5 \%$ of them watch less than one hour of TV before going to school, $16.5 \%$ of them watch $1-2$ hours of TV and $4.6 \%$ of them watch TV more than 2 hours.

Table 1: Frequency Table. Wachting TV before School

\begin{tabular}{|l|l|c|c|}
\hline \multicolumn{2}{|c|}{} & Frequency & Percent \\
\hline \multirow{4}{*}{ Valid } & Do Not See TV & 386 & 55.3 \\
\cline { 2 - 4 } & Less Than 1 Hours & 136 & 19.5 \\
\cline { 2 - 4 } & 1 till 2 Hours & 115 & 16.5 \\
\cline { 2 - 4 } & More Than 2 Hours & 32 & 4.6 \\
\cline { 2 - 4 } & Total & $\mathbf{6 6 9}$ & $\mathbf{9 5 . 8}$ \\
\hline Missing & System & 29 & 4.2 \\
\hline Total & $\mathbf{6 9 8}$ & $\mathbf{1 0 0 . 0}$ \\
\hline
\end{tabular}

Table 2 presents the results of children and adolescents regarding the amount of time they spend watching TV after returning from school. $15 \%$ of them do not watch TV after school, $27.9 \%$ of children and adolescents watch TV less than one hour, $40.7 \%$ of them watch 1 to 2 hours of TV, and $14.2 \%$ watch more than 2 hours.

Table 2: Wachting TV after School

\begin{tabular}{|l|l|c|c|}
\hline \multicolumn{2}{|c|}{} & Frequency & Percent \\
\hline \multirow{4}{*}{ Valid } & Do Not See TV & 105 & 15.0 \\
\cline { 2 - 4 } & Less Than 1 Hours & 195 & 27.9 \\
\cline { 2 - 4 } & 1 till 2 Hours & 284 & 40.7 \\
\cline { 2 - 4 } & More Than 2 Hours & 99 & 14.2 \\
\cline { 2 - 4 } & Total & $\mathbf{6 8 3}$ & $\mathbf{9 7 . 9}$ \\
\hline Missing & System & 15 & 2.1 \\
\hline Total & $\mathbf{6 9 8}$ & $\mathbf{1 0 0 . 0}$ \\
\hline
\end{tabular}

If we were to analyze the results referring to children's classes we notice that: 1 st grade students do not watch TV before going to school in $53.3 \%, 71.9 \%$ of fifth grade students do not watch TV, $9^{\text {th }}$ grade students don't watch TV at all in $48.5 \%$ of the results, and 12th grade students don't watch TV at all before going to school in $49 \%$ of the cases.

$22.8 \%$ of first grade students watch TV less than an hour before going to school, $13.2 \%$ of 5 th grade children watch TV less than an hour, $22.7 \%$ of 9th grade students watch TV less than an hour and $19.5 \%$ of 12 th grade students watch less than an hour before going to school.

In terms of watching TV 1-2 hours before going to school the results show $14.2 \%$ for first grade students, $10.2 \%$ for fifth grade students, $16 \%$ for 9 th grade students and $23.3 \%$ for 12 th grade students.

Regarding watching TV for more than 2 hours before going to school, the results in the following table show $3.9 \%$ for first grade students, $3.6 \%$ for 5 th grade students, $7.7 \%$ for students in the first grade. 9 th grade and $2.9 \%$ for 12 th grade students.

Table 3: Frequency Table. Wachting TV before School

\begin{tabular}{|l|l|l|c|c|}
\hline \multicolumn{2}{|l|}{ Grade } & Do Not See TV & Frequency & Percent \\
\hline \multirow{4}{*}{ Grade 1 } & \multirow{4}{*}{ Valid } & & 69 & 54.3 \\
\cline { 3 - 5 } & & Less Than 1 Hours & 29 & 22.8 \\
\cline { 3 - 5 } & 1 till 2 Hours & 18 & 14.2 \\
\cline { 2 - 5 } & More Than 2 Hours & 5 & 3.9 \\
\cline { 2 - 5 } & Total & $\mathbf{1 2 1}$ & $\mathbf{9 5 . 3}$ \\
\cline { 2 - 5 } & Missing & System & 6 & 4.7 \\
\cline { 2 - 5 } & Total & $\mathbf{1 2 7}$ & $\mathbf{1 0 0 . 0}$ \\
\hline
\end{tabular}




\begin{tabular}{|c|c|c|c|c|}
\hline \multicolumn{3}{|l|}{ Grade } & Frequency & Percent \\
\hline \multirow{7}{*}{ Grade 5} & \multirow{5}{*}{ Valid } & Do Not See TV & 120 & 71.9 \\
\hline & & Less Than 1 Hours & 22 & 13.2 \\
\hline & & 1 till 2 Hours & 17 & 10.2 \\
\hline & & More Than 2 Hours & 6 & 3.6 \\
\hline & & Total & 165 & 98.8 \\
\hline & Missing & System & 2 & 1.2 \\
\hline & \multicolumn{2}{|l|}{ Total } & 167 & 100.0 \\
\hline \multirow{7}{*}{ Grade 9} & \multirow{5}{*}{ Valid } & Do Not See TV & 94 & 48.5 \\
\hline & & Less Than 1 Hours & 44 & 22.7 \\
\hline & & 1 till 2 Hours & 31 & 16.0 \\
\hline & & More Than 2 Hours & 15 & 7.7 \\
\hline & & Total & 184 & $\begin{array}{ll}94.8 \\
\end{array}$ \\
\hline & Missing & System & 10 & 5.2 \\
\hline & \multicolumn{2}{|l|}{ Total } & 194 & 100.0 \\
\hline \multirow{7}{*}{ Grade 12} & \multirow{5}{*}{ Valid } & Do Not See TV & 103 & 49.0 \\
\hline & & Less Than 1 Hours & 41 & 19.5 \\
\hline & & 1 till 2 Hours & 49 & 23.3 \\
\hline & & More Than 2 Hours & 6 & 2.9 \\
\hline & & Total & 199 & 94.8 \\
\hline & Missing & System & 11 & 5.2 \\
\hline & \multicolumn{2}{|l|}{ Total } & 210 & 100.0 \\
\hline
\end{tabular}

Regarding the amount of time children and teenagers spend watching TV after returning from school, we can refer to the data in Table $4.18 .9 \%$ of first grade students do not watch TV after school, $12 \%$ of 5 th grade students do not watch TV after school, $16.5 \%$ of 9th grade students and $13.8 \%$ of 12 th grade students do not watch TV after school.

Referring to the study data we can say that $27.6 \%$ of the students in the first grade watch TV for less than an hour, $28.7 \%$ of the students in the fifth grade watch TV for less than an hour, $30.4 \%$ of the students in the classroom 9th and $25.2 \%$ of 12 th grade students watch TV for less than an hour after returning from school. $40.2 \%$ of first grade students, $47.9 \%$ of 5 th grade students, $33.5 \%$ of 9 th grade students and $41.9 \%$ of 12 th grade students watch TV for 1-2 hours after they return from school. $11 \%$ of first grade students watch TV for more than two hours when returning from school, and so do $10.8 \%$ of 5 th grade students, $17.5 \%$ of 9 th grade students, and $15.7 \%$ of 12 th grade students.

Table 4: Wachting TV after School

\begin{tabular}{|c|c|c|c|c|}
\hline \multicolumn{3}{|l|}{ Grade } & Frequency & Percent \\
\hline \multirow{7}{*}{ Grade 1} & \multirow{5}{*}{ Valid } & Do Not See TV & 24 & 18.9 \\
\hline & & Less Than 1 Hours & 35 & 27.6 \\
\hline & & 1 till 2 Hours & 51 & 40.2 \\
\hline & & More Than 2 Hours & 14 & 11.0 \\
\hline & & Total & 124 & 97.6 \\
\hline & Missing & System & 3 & 2.4 \\
\hline & \multicolumn{2}{|l|}{ Total } & 127 & 100.0 \\
\hline \multirow{7}{*}{ Grade 5} & \multirow{5}{*}{ Valid } & Do Not See TV & 20 & 12.0 \\
\hline & & Less Than 1 Hours & 48 & 28.7 \\
\hline & & 1 till 2 Hours & 80 & 47.9 \\
\hline & & More Than 2 Hours & 18 & 10.8 \\
\hline & & Total & 166 & 99.4 \\
\hline & Missing & System & 1 & .6 \\
\hline & \multicolumn{2}{|l|}{ Total } & 167 & 100.0 \\
\hline \multirow{7}{*}{ Grade 9} & \multirow{5}{*}{ Valid } & Do Not See TV & 32 & 16.5 \\
\hline & & Less Than 1 Hours & 59 & 30.4 \\
\hline & & 1 till 2 Hours & 65 & 33.5 \\
\hline & & More Than 2 Hours & 34 & 17.5 \\
\hline & & Total & 190 & 97.9 \\
\hline & Missing & System & 4 & 2.1 \\
\hline & \multicolumn{2}{|l|}{ Total } & 194 & 100.0 \\
\hline
\end{tabular}




\begin{tabular}{|l|l|l|c|c|}
\hline Grade & Fo Not See TV & Frequency & Percent \\
\hline \multirow{4}{*}{ Grade 12 } & \multirow{4}{*}{ Valid } & & 29 & 13.8 \\
\cline { 3 - 5 } & & Less Than 1 Hours & 53 & 25.2 \\
\cline { 3 - 5 } & & 1 till 2 Hours & 88 & 41.9 \\
\cline { 3 - 5 } & More Than 2 Hours & 33 & 15.7 \\
\cline { 2 - 5 } & Total & 203 & 96.7 \\
\cline { 2 - 5 } & Missing & System & 7 & 3.3 \\
\cline { 2 - 5 } & \multicolumn{2}{|l}{ Total } & $\mathbf{2 1 0}$ & $\mathbf{1 0 0 . 0}$ \\
\hline
\end{tabular}

The study also compared boys and girls. Table 5 shows the $\%$ differences between boys and girls regarding the time they watch TV before going to school and after returning from school. $53.9 \%$ of boys do not watch TV before going to school, $20.7 \%$ of them watch TV for less than one hour, $16.4 \%$ watch 1 to 2 hours and $5.3 \%$ more than 2 hours. While $56.4 \%$ of girls do not watch TV before going to school, $18.2 \%$ of them watch less than an hour, $16.6 \%$ of them watch 1 to 2 hours and $4.1 \%$ of them watch more than 2 hours of TV before go to school.

Table 5: Watching TV before School

\begin{tabular}{|c|c|c|c|c|}
\hline \multicolumn{5}{|c|}{ Wachting_TV_before_School } \\
\hline Gender & & & Frequency & Percent \\
\hline \multirow{7}{*}{ Boy } & \multirow{5}{*}{ Valid } & Do Not See TV & 174 & 53.9 \\
\hline & & Less Than 1 Hours & 67 & 20.7 \\
\hline & & 1 till 2 Hours & 53 & 16.4 \\
\hline & & \begin{tabular}{|l} 
More Than 2 Hours \\
\end{tabular} & 17 & 5.3 \\
\hline & & Total & 311 & 96.3 \\
\hline & Missing & System & 12 & 3.7 \\
\hline & Total & & 323 & 100.0 \\
\hline \multirow{7}{*}{ Girl } & \multirow{5}{*}{ Valid } & Do Not See TV & 204 & 56.4 \\
\hline & & Less Than 1 Hours & 66 & 18.2 \\
\hline & & 1 till 2 Hours & 60 & 16.6 \\
\hline & & More Than 2 Hours & 15 & 4.1 \\
\hline & & Total & 345 & 95.3 \\
\hline & Missing & System & 17 & 4.7 \\
\hline & Total & & \begin{tabular}{l|l}
362 \\
\end{tabular} & 100.0 \\
\hline
\end{tabular}

Whereas the TV watch time values for boys and girls after school are as in Table $6.17 .3 \%$ of boys do not watch TV after school, $27.9 \%$ of boys watch TV less than an hour, $41.2 \%$ of them watch TV 1 to 2 hours, and $11.1 \%$ of them watch more than two hours of TV after school. $13 \%$ of girls do not watch TV when they return from school, $27.9 \%$ of girls watch TV less than an hour, $40.1 \%$ watch 1 to 2 hours of TV and $17.1 \%$ of girls watch more than 2 hours of TV after return from school.

Table 6: Watching TV after School

\begin{tabular}{|c|c|c|c|c|}
\hline \multicolumn{5}{|c|}{ Wachting_TV_after_School } \\
\hline \multicolumn{3}{|c|}{ Gender } & Frequency & Percent \\
\hline \multirow{7}{*}{ Boy } & \multirow{5}{*}{ Valid } & Do Not See TV & 56 & 17.3 \\
\hline & & Less Than 1 Hours & 90 & 27.9 \\
\hline & & 1 till 2 Hours & 133 & 41.2 \\
\hline & & \begin{tabular}{|l} 
More Than 2 Hours \\
\end{tabular} & 36 & 11.1 \\
\hline & & Total & 315 & 97.5 \\
\hline & Missing & System & 8 & 2.5 \\
\hline & Total & & 323 & 100.0 \\
\hline \multirow{7}{*}{ Girl } & \multirow{5}{*}{ Valid } & Do Not See TV & 47 & 13.0 \\
\hline & & Less Than 1 Hours & 101 & 27.9 \\
\hline & & 1 till 2 Hours & 145 & 40.1 \\
\hline & & More Than 2 Hours & 62 & 17.1 \\
\hline & & Total & 355 & 98.1 \\
\hline & Missing & System & 7 & 1.9 \\
\hline & \multicolumn{2}{|l|}{ Total } & 362 & $\mathbf{1 0 0 . 0}$ \\
\hline
\end{tabular}

This study also examined the differences between boys and girls in each of the classes before they went to school and after they returned from school.

There are $51.7 \%$ of first grade boys who do not watch TV before going to school and $57.4 \%$ for the girls. $25.9 \%$ of Boys watch TV less than 1 hour while $20.6 \%$ of girls watch TV for less than one hour. $15.5 \%$ of boys watch TV for $1-2$ hours while girls are at $11.8 \% .3 .4 \%$ of boys watch TV for more than 2 hours while for girls it's $4.4 \%$. 
Results show that $70.9 \%$ of fifth grade boys do not watch TV before school while for girls it's $73.8 \%$. Boys who watch less than 1 hour of TV are $11.6 \%$ while $13.8 \%$ of girls watch less than an hour of TV. Boys who watch TV for $1-2$ hours result at $12.8 \%$ while girls at $7.5 \% .4 .7 \%$ of boys watch TV for more than 2 hours while for girls it's $2.5 \%$.

$45.9 \%$ of the ninth grade boys do not watch TV before school whereas for girls it's $51.8 \%$. Boys who watch less than 1 hour of TV are $26.6 \%$ while girls who watch less than one hour of TV are $17.6 \%$. Boys who watch TV for $1-2$ hours are $14.7 \%$ while girls are $17.6 \% .8 .3 \%$ of boys watch TV for more than 2 hours while for girls it's $7.1 \%$.

$41.1 \%$ of 12 th grade boys do not watch TV before school while for girls it's at $48.1 \%$. Boys who watch less than 1 hour of TV are $18.6 \%$ while girls who watch less than one hour of TV are $20.2 \%$. Boys who watch TV for $1-2$ hours are $24.3 \%$ while girls are $24 \% .2 .9 \%$ of boys watch TV for more than 2 hours while for girls its $3.1 \%$.

Data from the examination showed that $20.7 \%$ of boys in the first grade do not watch TV after school and girls $17.6 \%$. Boys who watch less than 1 hour of TV are $27.6 \%$ while girls who watch less than one hour of TV are $26.5 \%$. Boys who watch TV for $1-2$ hours are $37.9 \%$ while girls are 42.6\%. $12.1 \%$ of boys watch TV for more than 2 hours while results show $10.3 \%$ for girls. $16.3 \%$ of fifth grade boys do not watch TV after school and $7.5 \%$ for girls. Boys who watch TV less than 1 hour are $24.4 \%$ while girls who watch TV less than one hour are $32.5 \%$. Boys who watch TV for $1-2$ hours are $52.3 \%$ while girls are $43.8 \%$. There are $7 \%$ of boys that watch TV for more than 2 hours while girls are $15 \%$.

In the ninth grade, boys who do not watch TV after school are $19.3 \%$ and girls $12.9 \%$. Boys who watch less than 1 hour of TV are $33 \%$ while girls who watch less than one hour of TV are $27.2 \%$. Boys that watch TV for $1-2$ hours are $32.1 \%$ while girls are $35.3 \% .12 .8 \%$ of boys watch TV more than 2 hours while $23.5 \%$ for girls.

In 12th grade boys who do not watch TV after school are $12.9 \%$ and girls $14 \%$. Boys who watch TV less than 1 hour are $24.3 \%$ while girls who watch TV less than one hour are $26.4 \%$. Boys who watch TV for $1-2$ hours are $44.3 \%$ while girls are $39.5 \% .12 .9 \%$ of boys watch TV more than 2 hours in comparison to girls that are $17.8 \%$.

\section{Discussion}

One of the main goals of this study is to find whether children and adolescents watch more TV before going to school or after returning from school. The study results, referring to Tables 1 and 2 , clearly show that they watch more TV after returning from school. A large number of them do not watch TV before going to school while a small number do not watch TV after school. After school, the highest percentage of them watches 1-2 hours of TV. According to (AAP, 2011) the optimal time that children and adolescents should watch TV is 1 to 2 hours a day, which coincides with the time that the highest number of children and adolescents watch TV.

Another purpose of the study is to find out who watches more TV between boys and girls. The results of the study, in Tables 5 and 6, show that the difference between boys and girls is not significant, they are approximately the same. Even according to a study by (Moroëatisharifabad, Karimi \& Ghorbanzadeh, 2015), statistically the difference between boys and girls when they watch TV has proved to be insignificant.

From the study we can also see the difference between the groups depending on their classes. It turns out that the differences between the groups are minimal. If we refer to how long they watch TV before going to school, those who watch less are fifth grade children while those that watch more than two hours are mostly 9th grade children. Even the children that watch TV after school the differences between the groups are not significantly noticeable, but those that watch more than two hours are mostly 9th and 12th graders. According to (ACP, 2016), teenagers spend more time watching TV than children because their parents do not dilute the rules on the hours they have to spend in front of TV at this age. If during childhood parents are very controlling towards children both on the hours they watch TV and on programming. In teens, parents care more about the programs they watch rather than the hours they spend watching. Even according to a study done by (Robinson, 2011), in the US, in which both children and adolescents participated, children 
spent an average of 2.5 hours per day watching TV and adolescents averaged 4.5 hours per day.

The study gives us data on a significant number of children and adolescents, which is a strong point of study. The other strong point of the study is that both boys and girls were studied, making possible a comparison between them.

The strong point of the study is also that it has received a wide age distribution of the students in 4 different age groups.

But the study was conducted only in the city of Tirana and not in the whole of Albania, making it a demographically limited study.

\section{Conclusion and Recommendations}

In conclusion, we can say that Albanian children and adolescents in the study spend a considerable amount of 1 hour to 2 hours of TV per day. This is an acceptable amount for their age. They watch more TV after returning from school than before going to school. No statistically significant differences were observed between boys and girls. And, by comparing the 4 groups of children surveyed, teenagers are the ones who watch the most TV. Despite the problems that Watching TV causes with long hours, we can also say that if it is watched part-time and in appropriate programming it can also have a positive impact on the development of children and teenagers.

It is recommended that children and adolescents reduce the amount of time they watch TV and increase the amount of time they engage in physical activities to reduce the number of problems caused by it.

It is recommended that another study be carried out to study children and adolescents throughout Albania and not only in Tirana.

It is recommended that there should be promotion of more physical activities in children's education programs.

It is recommended that parents control the length of time and television programming of their children.

\section{References}

American Academy Of Pediatrics. (2001). Children, Adolescents, and Television. Pediatrics Volume 107 / Issue 2, 423-425

American Academy of Child e Adolescent Psychiatry (2014). TV Violence and Children. FFF, Nr.13, American Collage of Pediatricions. (2016). The impact of media use and screen time on children, adolescents and families. Teen Health and Media

Baron, M. (2000). The effects of television on child health: implications and recommendations. NCBI, Volume 83 , Issue 4

Gortmakers, S. (2006). Television Viewing as a Cause of Increasing Obesity Among Children in the United States, 1986-1990. Arch Pediatr Adolesc Med. 356-362.

Jarani. J, Spahi. A, Muca. F, Qefalia. D, Tarp. J, Groentved. A, Kasa. A, Shaka. L and Ushtelenca. K (2016). A cross section study on obesity of Albania children living in Balkan area, European Journal of Health \& Science in Sports Volume 3(2) Page 1-6

Jarani. J, Spahi. A, Grontved. A, Muca. F and Tarp. J, (2018), Prevalence of overweight and obesity and anthropometric reference centiles for Albanian children and adolescents living in four Balkan nationstates, Journal of pediatric endocrinology \& metabolism. JPEM 31(11)

Karaj, Th. (2005). Psikologjia e Zhvillimit të Fëmijës. Progres, 248

Kostyrka, K; Cooper. R: Simpson, A. (2017). The relationship between television exposure and children's cognition and behaviour: A systematic review. ELSEVIER, Volume 44, 19-58

Liebert, RM. (1986). Effects of television on children and adolescents. Journal of Developmental and Behavioral Pediatrics, 43- 48.

Morowatisharifabad, M.,Karimi, M., Ghorbanzadeh, F. (2015). Watching television by kids: How much and why? Journal of Education and Health Promotion,

Robinson, Th. 2001. Television viewing and childhood obesity. Pediatric Clinics of North America, Volume 48, Issue 4, 1017-1025

Strasburger, VC. (1986). Does television affect learning and school performance? Pediatrician, 141-7.

Villanim, S. (2001). Impact of Media on Children and Adolescents: A 10-Year Review of the Research. Journal of the American Academy of Child \& Adolescent Psychiatry, Volume 40, Issue 4, 392 